\title{
丛枝菌根真菌对植物次生代谢的影响
}

\author{
赵 昕 阎秀峰* \\ (东北林业大学生命科学学院, 哈尔滨 150040)
}

\begin{abstract}
摘 要 丛枝菌根 $(\mathrm{AM})$ 是自然界中分布最为广泛、最为重要的一类菌根, 许多研究已经观察到丛枝菌根真菌与植 物次生代谢的相关性，从枝菌根真菌能够直接或间接地影响植物的次生代谢过程。植物的次生代谢产物主要分为 萜类物质、酚类物质和含氮化合物 (主要是生物碱)三大类群, 该文简要介绍了丛枝菌根真菌对这 3 类植物次生代 谢产物的影响。丛枝菌根真菌与萜类物质代谢关系的研究比较细致和深入,有些工作已经从细胞及分子水平探讨 其间的作用机制, 如 Blumenin、类胡夢卜素等。丛枝菌根真菌与酚类物质代谢关系的研究也比较深入, 其中具有特 殊功能的酚类物质一一植保素、细胞壁酚酸、类黄酮/异类黄酮等倍受关注。目前有关丛枝菌根真菌与生物碱关系 的研究相对较少, 不过现有的研究表明, 菌根的形成有助于生物碱积累。
\end{abstract}

关键词 丛枝菌根 植物次生代谢 萜类 酚类 生物碱

\section{EFFECTS OF ARBUSCULAR MYCORRHIZAL FUNGI ON PLANT SECONDARY METABOLISM}

\author{
ZHAO Xin and YAN Xiu-Feng ${ }^{*}$ \\ ( College of Life Sciences, Northeast Forestry University , Harbin 150040 , China)
}

\begin{abstract}
Mycorrhizal fungi form the most important mutualistic symbioses on earth with plants. The most prevalent type of mycorrhizal fungi are the arbuscular mycorrhizal (AM) fungi. Much research has shown that the development of AM fungi is correlated with plant secondary metabolism. AM fungi can directly or indirectly affect plant secondary metabolic processes. Secondary metabolites are classified into 3 groups, terpenoids, phenolics and alkaloids. In this paper, we summarize the effects of AM fungi on the 3 groups of secondary metabolites.
\end{abstract}

The relationship between terpenoids and AM fungi have been well studied, and some research has explored interactive mechanisms at the molecular level. Blumenin was first isolated and identified from mycorrhizal cereals, and its biosynthesis has been proven via the Glyceraldehyde 3-phosphate/ pyruvate pathway (MEP) by an isotopic labeling method. Since then , the accumulation of blumenin induced by AM fungi and differences in blumenin levels among different kinds of AM fungi have been observed. Studies on 1-deoxy-Dxylulose-5-phosphate synthase (DXS) and 1-deoxy-D-xylulose-5-phosphate reductoisomerase (DXR), two key enzymes in the biosynthesis of carotenoid metabolism via the MEP pathway, have found to increase the transcription of DXS and DXR in plants with AM fungi. Moreover it was temporarily and spatially correlated with the accumulation of apocarotenoids. Subsequently, two genes were identified : TC78589 encoding DXS2 which is highly expressed in roots inoculated with AM fungi , and TC77051 encoding mevalonate disphosphate decarboxylase, which is catalysed in the synthesis of terpenoids in the mevalonate pathway. Although both genes separately encode enzymes in different pathways, an enhancement of carotenoid biosynthesis has been observed.

The interaction between phenolic compounds ( such as phytoalexin, wall-bound phenol , flavonoids, isoflavonoids and their derivatives) and AM fungi also has been investigated intensively. It has been shown that some flavonoids stimulated the spore germination and hyphal growth of AM fungi, and the contents of flavonoids increased before the infection of AM fungi. Therefore some investigators hypothesized that flavonoids were a signal compound during the formation of AM fungi. Afterward, increased levels of flavonoids were found after the formation of AM fungi which was related to specific species of AM fungi. In addition, some experiments have indicated that the activity of peroxidase (POD) , phenylalanine ammonia-lyase (PAL) and polyphenol oxidase ( $\mathrm{PPO}$ ) were significantly enhanced in AM plants. In phenylpropamoid metabolism, there are two differ- 
ent signaling pathways in the accumulation of secondary metabolites induced by the mycorrhizal fungus : one is through the induction of PAL and chalcone synthase (CHS), and the other is through the suppression of isoflavone reductase (IFR).

Although little research seldom has examined the relationship between alkaloids and AM fungi, a recent study has shown that the formation of AM is beneficial to the accumulation of alkaloids. This study also showed the species specificity in AM affected biosynthesis of alkaloids.

Key words Arbuscular mycorrhizal (AM) , Plant secondary metabolism , Terpenoids , Phenolics , Alkaloids

菌根是自然界中一种极为普遍和重要的共生现 象, 其中分布最为广泛的菌根类型就是丛枝菌根 (Arbuscular mycorrhiza，AM) , 它是由陆生植物根和接 合菌纲的真菌共生发育而成的 (Strack et al. , 2003 ，自然界中约有 $90 \%$ 的维管植物都能形成丛枝 菌根(刘润进和李晓林,2000)。丛枝菌根真菌可以 在植物根系皮层细胞内和细胞间形成菌丝体, 并且 在侵入的根系皮层细胞内菌丝连续二分叉形成树枝 状或花椰菜状结构，即所谓的丛枝结构，它负责进行 菌根真菌和宿主植物之间的物质交换，由植物向真 菌转运碳水化合物, 并将矿质营养尤其是磷素和水 分提供给植物。丛枝菌根真菌显著影响植物的初生 代谢过程(Smith \& Read，1997)，它可以促进植物根 系对磷、铜、锌、镉等矿质元素及养分的吸收 (Hamel , 1996 ; Dodd et al . 2002) 调节植物激素的合成和分 配(Barker \& Tagu，2000)，改善植物的根际微生物环 境并增强植物的抗病性 (Hooker et al . , 1994 ;Graham , 2001)，同时提高植株对环境胁迫的耐受力 (Stahl et al ., 1998 ;Augé ，2001），从而全面改善宿主 植物的生长状况 (Jones et al ., 1998 ; Varma， 1998 ; Rai et al. ,2001)。

植物的次生代谢与初生代谢密不可分, 是植物 在长期进化中与环境 (生物的和非生物的)相互作用 的结果, 次生代谢产物在植物提高自身保护和生存 竞争能力、协调与环境关系上起着不可替代的重要 作用，其产生和变化比初生代谢产物与环境有着更 强的相关性和对应性(陈晓亚和叶和春, 1998;Fraser \& Grime , 1999 ;Massei et al. , 2000 ;Shelton , 2000 ; ;阎 秀峰, 2001)。近年来, 许多研究表明丛枝菌根真菌 也影响植物的次生代谢过程，导致植物的次生代谢 产物发生变化（Morandi， 1996 ; Vierheilig et al. , 1998）,而这些次生代谢产物在植物和菌根真菌之间 形成的共生关系中岂着特别重要的作用 (Harborne， 1988 ; Akiyama et al. , 2002)。因此, 研究菌根真菌 和植物次生代谢的关系具有非常重要的生态学意 义。植物的次生代谢产物种类繁多、数量庞大, 为研 究方便, 习惯上分为萜类、酚类和含氮化合物 (主要
是生物碱)三大类群。本文将围绕这三大类群次生 代谢物质简要介绍丛枝菌根真菌对植物次生代谢的 影响。

\section{1 丛枝菌根真菌与植物的萜类物质代谢}

萜类化合物是以异戊二烯为基本结构单位的一 类化合物,也称为类异戊二烯衍生物，人们在许多形 成丛枝菌根的植物中发现, 菌根真菌能够显著促进 某些类异戊二烯行生物含量的增加, 这显然与植物 的次生代谢过程有关 (Janardhanan \& Abdul-Khaliq， 1995 ; Maier et al., 1999 ;冷平生等, 2001 ;Gupta et al ., 2002 ; Akiyama \& Hayashi , 2002)。

1.1 丛枝菌根真菌对倍半萜环己烯酮衍生物的影 响

Maier 等 (1997) 在形成丛枝菌根的禾本科植物 中发现倍半萜环己烯酮衍生物的含量增加，他们认 为丛枝菌根真菌诱导倍半萜环己烯酮衍生物的积累 在禾本科植物中是较为普遍的现象, 菌根共生体的 形成与这些萜类化合物的代谢密切相关。

在倍半萜环己烯酮衍生物中对 Blumenin 的研 究最为集中, 这种化合物的化学名称为 9-O- (2' -O- $\beta-$ 吡喃葡萄糖醛酸基) - $\beta$-吡喃葡萄糖苷-6-(3-差王丁基)1,5-三甲基-4-环己烯-3-酮 [9-O-(2' -O- 1 -glucuronosyl )- $\beta$-glucopyranoside of 6-( 3-hydroxybutyl )-1,1,5trimethyl-4-cyclohexen-3-one]。Maier 等 (1995) 采用核 磁共振技术和质谱分析方法首次在接种根内球囊霉 (Glomus intraradices) 的谷类作物中分离并鉴定了 Blumenin,其后发现大麦 (Hordeum vulgare)、小麦 ( Triticum aestivum) 、黑麦( Secale cereale ) 和燕麦(Avena sativa) 的菌根中 Blumenin 的含量均比对照显著增 加, 并且 Blumenin 的含量与菌根真菌的侵染率呈现 出正相关性 据此他们认为 Blumenin 与菌根的形成 有关 (Maier et al. , 1995)。随后, 他们又利用同位素 标记技术研究了大麦菌根中 Blumenin 的生物合成 途径，发现它是通过 MEP 途径产生的(Maier et al. , 1998)。最初曾认为萜类化合物的唯一生物合成前 体是甲羟戈酸, 但后来的研究发现, 在植物细胞器质 
体中还存在着第二条途径一一非依赖甲羟戊酸途 径, 即丙酮酸/3-磷酸甘油醛途径(陈大华等,2000)。 该途径中的一个重要中间体为 4-磷酸甲基赤藓糖 醇，因此又称为磷酸甲基赤藓糖醇( MEP)途径。

1999 年在非禾本科植物烟草 (Nicotiana tabacum) 中也发现了丛枝菌根真菌诱导 Nicoblumenin 积累的现象 (Maier et al . , 1999)。此后,Vierheiling 等(2000) 分别用 3 种丛枝菌根真菌, 即根内球囊霉、 漏斗孢球囊霉 (Glomus mosseae)、玫瑰红巨孢囊霉 (Gigaspora rosea) 与玉米 (Zea mays)、大麦和小麦进 行单接种试验, 发现不同种类的丛枝菌根真菌形成 的菌根植物中 Blumenin 的含量有显著差异, 表明丛 枝菌根真菌的种类会影响到 Blumenin 的含量。

Fester 等 (1999) 在大麦和小麦的根中接种丛枝 菌根真菌后又接入菌根助成菌 (Mycorrhization helper bacteria，MHB）发现丛枝菌根真菌在菌根助成菌的 帮助下增强了侵染根的能力, 促进了植物对营养的 吸收，加快了植物的生长，同时也提高了植物根中 Blumenin 的含量。他们推测可能是接种的菌根助成 菌促使植物细胞壁裂解酶活性增强, 导致细胞壁变 软, 易于菌根真菌的侵入, 使得菌根真菌的侵染率提 高，从而导致 Blumenin 积累的结果 (Fester et al. , 1999)。同时他们又发现 给菌根植物添加外源 Blumenin, 会出现抑制菌根形成和发育的现象。Fester 等(1999)认为外源 Blumenin 抑制菌根真菌丛枝细胞 的产生, 阻碍菌根的形成和滞后生长, 这可能是由于 Blumenin 抑制了某些化合物在菌根中的合成, 而导 致植物瞬时防御反应机制的启动，从而阻碍丛枝菌 根真菌的侵入 抑制菌根的发育。

\section{2 丛枝菌根真菌对其它萜类化合物的影响}

经由 MEP 途径生成的萜类化合物不仅只有倍 半萜环己烯酮衍生物，一些激素如脱落酸、赤霉素以 及与光合作用有关的色素如类胡夢卜素等均来源于 MEP 途径 (Lois et al . , 2000)。在由 MEP 途径产生 的萜类化合物中, 人们已经观察到丛枝菌根真菌与 类胡萝卜素、脱落酸的代谢有关 (Walter et al. , 2000 ; Hause et al . , 2002)。

Maier 等 (1998) 首次在实验中观察到丛枝菌根 真菌诱导植物根中光合色素积累的现象, 认为丛枝 菌根真菌可能是导致根中类胡夢卜素形成的直接原 因, 并且已经证明丛枝菌根中类胡萝卜素的合成是 来源于 MEP 途径。在质体中进行的 MEP 途径第一 步就是由 1-脱氧-5-磷酸-D-木酮糖合成酶 (1-deoxyD-xylulose-5-phosphate synthase，DXS) 来催化完成的。
以前认为它是由单克隆基因编码的,而Walter 等 (2002)却从豆科植物模式种苜宿 (Medicago truncatu$l a)$ 中分离到了两个独立的类似 DXS 的 cDNA 序列， 并且由 cDNA 序列翻译出两个蛋白 MtDXS1 和 MtDXS2，不过序列分析表明这两个蛋白中没有人们已 知的定位质体的多肽序列。这两个蛋白的分子量很 接近 (分别是 72.7 和 $71.2 \mathrm{kDa}$ ),但它们的氨基酸序 列同源性很小, 只有 $70 \%$ 。分离得到的两个 cDNA 序列在大肠杆菌 (Escherichia coli)中表达, 都能得到 具有 DXS 酶活性的蛋白。对苜宿、玉米、蕃茄 ( $L y-$ copersicon esculentum) 和烟草的 RNA 印迹分析表明， DXS1 基因在根以外的其它生长组织中高表达,而 DXS2 的转录水平在这些组织中恰恰很低。但是, 在 接种丛枝菌根真菌的植物根中 DXS2 的转录水平升 高, 并与类胡萝卜素以及类胡夢卜素氧化分解产物 的积累呈现相关性，暗示这种特异的基因表达结果 是由丛枝菌根真菌引起的。Hohnjec 等 (2005) 也得 到一致的结果, 他们研究了 30 种编码次生代谢合成 途径中催化酶的基因，发现它们都受到丛枝菌根的 调控 其中的 TC78589 (DXS2) 和 TC77051 是与萜类 物质代谢相关的基因。TC78589(DXS2)编码 1-脱氧5-磷酸-D-木酮糖合成酶, 在该酶的作用下经由 MEP 途径合成异戊烯基二磷酸，它是合成萜类化合物的 前体。同时他们又发现 TC77051 是编码甲羟戊酸二 磷酸脱羧酶的基因，在该酶的催化作用下经过甲羟 戊酸途径也可以合成萜类物质。所以, 尽管两个基 因分别编码不同途径的催化酶, 但最终有利于萜类 物质合成。

Hans 等(2004)研究了催化 MEP 途径的另一个 关键酶, 即 1-脱氧-5-磷酸-D-木酮糖还原异构酶 (1deoxy-D-xylulose-5-phosphate reductoisomerase, DXR ) , 他们在接种了丛枝菌根真菌的玉米根中发现，丛枝 菌根中丛枝结构的发育与 DXR 活性蛋白的积累是 密切相关的, 发育成熟的丛枝结构中 DXR 活性显著 增强。在接种丛枝菌根真菌的小麦、玉米、水稻 $(O-$ ryza sativa) 和大麦根中, MEP 途径的两个关键酶 DXS 和 DXR 的转录水平均比对照高, 并且类胡萝卜素氧 化分解产物同步积累 (Walter et al.,2000)。Fester 等(2002a)认为丛枝菌根的发育不仅与类胡夢卜素 氧化分解产物的合成有关, 而且诱导了类胡夢卜素 的代谢。他们推测这种 MEP 途径关键酶在植物根 中表现活跃的现象可能是由丛枝菌根真菌引起的， 并且在菌根形成和发育的过程中类胡夢卜素很可能 起到重要作用。 
虽然研究者们发现丛枝菌根真菌与植物体内类 异戊二烯化合物的代谢有关 (Danneberg et al. , 1993 ;Klingner et al . , 1995 ;Fester et al . 2002a), 但 有关作用机理的研究还很少见( Fester et al. , 2002b)。

\section{2 丛枝菌根真菌与植物的酚类物质代谢}

\section{1 丛枝菌根真菌对植物酚类化合物的影响}

Dehne 和 Schönbeck (1979) 首先注意到丛枝菌根 真菌与植物酚类物质的积累有关, 他们发现接种漏 斗孢球囊霉可以使番茄中木质素和可溶性酚的含量 增加。随后的研究又发现漏斗孢球囊霉还引起踠豆 (Pisum sativum) 根系内总酚酸类物质含量的提高 ${ }^{1)}$ (Singh et al . , 2004) , 而聚生球囊霉 (Glomus fasciculatum) 可提高落花生 (Arachis hypogaea) 根系内总酚 酸类物质的含量 (Krishna \& Bagyaraj , 1984)。Devi 和 $\operatorname{Reddy}(2002)$ 研究发现, 接种了漏斗孢球囊霉的落花 生根系和地上部酚类物质的含量均增加，同时他们 又进行了丛枝菌根真菌与根瘤菌双接种试验，结果 表明 双接种的落花生中酚类物质的含量高于单接 种的处理。

后来，在丛枝菌根真菌对酚类物质影响的研究 中, 人们开始关注具有特殊功能的酚类物质一一植 保素、细胞壁酚酸、类黄酮/异类黄酮等 (Vierheilig， 2004)。例如, 大豆 (Glycine max) 菌根形成后, 其根 部的植保素积累,其中主要是大豆素 (Morandi et $a l$ ，，1984），苜宿接种地表球囊霉( Glomus versiforme) 7 13 d 根系中苜宿素含量增加 (Harrison \& Dixon , 1993)。同样, 在接种根内球囊霉和地表球囊霉的洋 葱 (Allium cepa) 中 细胞壁酚酸阿魏酸和 4-对羟基桂 皮酸含量增加 (Grandmaison et al , , 1993)。普遍观 点认为这主要是因为酚酸类化合物增多, 会导致细 胞壁增厚，从而形成抗病菌入侵的天然屏障 (Volpin et al ， 1994 ; Harrison，1999)。然而也有试验显示， 丛枝菌根植物中细胞壁酚酸类物质的含量没有增 加。例如 非憼 (Allium porrum) 和银杏 (Ginko biloba) 被地表球囊霉侵染后，根中细胞壁酚酸物质的含量 没有明显变化 (Codignola et al . , 1989)。这与 Maier 等(1995)的研究结果类似, 他们在大麦、小麦、黑麦 和燕麦 4 种谷类作物中接种了根内球囊霉, 侵染后 检测根中香豆酸和阿魏酸的含量, 发现与对照植物
无显著差异。Peipp 等 (1997) 在大麦菌根细胞中也 发现类似的情况, 但是这并没有影响到菌根植物的 抗病性,他们认为, 可能是一些非羟基聚合酚类化合 物的含量增加, 导致细胞壁木质化加强, 同样能够增 强菌根植物的抗病性。

一些研究者认为, 黄酮类物质能够促进孢子萌 发、菌丝生长以及菌根真菌的侵染 (Poulin et al. , 1993 ;Vierheilig et al . , 1998) , 是菌根形成的信号传 导物质 (Larose et al. ，2002)。Larose 等(2002) 用漏 斗孢球囊霉、根内球囊霉和玫瑰红巨孢囊霉分别接 种紫苜宿 (Medicago sativa) , 发现在菌根真菌侵染之 前 植物体内黄酮类物质增多, 并且在 3 种不同真菌 的菌根中黄酮类物质的含量有显著差异，据此他们 认为黄酮类物质不仅与建立菌根共生体的信号有 关, 还表现出菌根真菌种类的特异性。另外一些研 究还显示, 菌根形成之后也会增加黄酮类物质的含 量 (Akiyama et al 。,2002)。Ponce 等(2004)在白车轴 草( Trifolium repens) 接种根内球囊霉的实验中发现， 栎皮酮、金合欢素和鼠李黄素出现积累的现象。上 述结果表明无论是侵染前还是侵染后丛枝菌根真菌 都可能刺激黄酮类物质增多。

异黄酮类物质在结构上与黄酮类物质相似，功 能也相近。不过丛枝菌根真菌对这类物质的影响却 与黄酮类不尽相同。接种丛枝菌根真菌后, 植物中 异黄酮类物质的含量有的增加、有的减少。例如 地 表球囊霉侵染苜宿和紫苜宿后, 异黄酮丙二酰糖苷 (Formononetin malonyl glucoside)和紫苜宿素丙二酰糖 苷(Medicarpin malonyl glucoside)的含量增加，而根内 球囊霉侵染苜宿的根系后, 异黄酮-7-氧基糖苷 (Formononetin-7-O-glycoside ) 和紫苜宿素-3-氧基糖苷 (Medicarpin-3-O-glycoside) 的含量则减少 (Volpin et al . , 1995)。

\section{2 丛枝菌根中酚类物质代谢相关酶的研究}

Dehne和 Schönbeck (1979) 报道，接种漏斗孢球 囊霉的番茄中过氧化物酶 (POD) 和苯丙氨酸解氨酶 (PAL)的活性显著增强。

过氧化物酶 (POD) 在酚类化合物聚合成木质素 时起重要作用。它的一个重要特性就是催化细胞壁 酚类化合物氧化形成更疏水的聚合物如木质素, 这 可以加固细胞壁, 减少植物被病原菌侵染的可能性。 所以,POD 是植物提高自身抗病性的物质代谢基础。

1) Ghachtouli EN (1995). Polyamines and mycorrhiza development in mycorrhiza-susceptible $\left(\mathrm{Myc}^{+}\right)$and resistant $\left(\right.$Myc $\left.^{-}\right)$pea genotypes. Doctoral Thesis. Burgundy University, Dijon , France , 222. 
Spanu 和 Bonfante-Fasolo ( 1988 ) 发现,地表球囊霉与 非忽在形成菌根时 根中细胞壁 POD 酶活性显著增 强, 而在接种了漏斗孢球囊霉的落花生根部过氧化 物酶 (POD) 和多酚氧化酶 (Polyphenol oxidase ,PPO)的 活性也有所升高(Devi \& Reddy , 2002)。

苯丙氨酸解氨酶 (PAL) 是苯丙烷类代谢途径中 的关键酶, 也是研究得最多的一个酶。Blilou 等 (2000) 在水稻接种漏斗孢球囊霉后, 研究菌根中 PAL 和脂质转运蛋白 (Lipid transfer protein, LTP) 基 因的表达 发现 LTP 基因的表达是受菌根真菌调控 的，而 LTP 基因的表达则伴随着 PAL 基因的表达， 反映出丛枝菌根真菌间接诱导 PAL 的活性变化过 程。紫苜宿的根系被丛枝菌根真菌侵染的早期, 黄 酮类物质积累, PAL 和查尔酮异构酶 (Chalcone isomerase，CHI) 表现活跃( Volpin et al.,1995)。地表 球囊霉侵染苜宿后, 菌根中 PAL 和查耳酮合成酶 (Chalcone synthase CHS , 是合成类黄酮/异类黄酮化 合物途径的第一个酶) 的转录水平均得到提高, 而同 时异类黄酮还原酶 (Isoflavone reductase IFR, 是紫苜 宿素合成途径的倒数第二个酶) 的转录水平受到抑 制(Harrison \& Dixon, 1993)。因此他们认为, 在细胞 水平上, 苯丙烷类代谢途径中被丛枝菌根真菌诱发 的次生物质的积累信号途径有两条:一是诱导 PAL 和 CHS , 另一条是抑制 IFR。

\section{3 丛枝菌根真菌与植物的生物碱代谢}

目前丛枝菌根真菌对植物生物碱影响的研究相 对较少, 多数集中在具有药用价值的植物上。魏改 堂和汪洪钢 (1989) 在不同土壤有效磷供给条件下用 漏斗狍球囊霉和地表球囊霉分别接种曼陀罗 (Datura stramonium) , 发现丛枝菌根真菌显著提高了曼陀 罗中莨菪碱和东莨菪碱的含量。他们认为, 莨菪碱 和东莨若碱含量的增加可能是丛枝菌根真菌提高植 物激素的水平所致，丛枝菌根真菌不仅能增强植物 对磷素营养的吸收, 还可能促进植物体内激素的形 成，从而引起宿主植物在次生代谢上发生变化。Rojas-Andrade 等(2003)在研究玫瑰红巨狍囊霉接种牧 豆树 (Prosopis laevigata) 时,用高效液相色谱 (HPLC) 检测牧豆树菌根中的甲醇提取物，显示一种可被紫 外吸收的物质含量发生变化, 后用核磁共振技术和 质谱分析方法鉴定为葫芦巴碱 (Trigonelline, 一种吡 啶生物碱)。在研究中他们发现, 无论是否有菌根真 菌的侵染，牧豆树地上部分葫芦巴碱的含量总是恒 定不变的, 而在菌根真菌侵染的根中其含量比对照
增加了 1.8 倍, 他们认为葫芦巴碱可能在牧豆树被 菌根真菌侵染时起到重要的作用。

Abu-Zeyad 等(1999) 研究了丛枝菌根真菌对澳 大利亚粟籽豆 (Castanospermum australe) 中粟籽豆碱 (Castanospermine, 一种吲哚生物碱) 含量的影响。他 们选择了 3 处采集地, 分别收集自然生长的粟籽豆 的各个部位 (种子、根、叶片) 以及根际土壤。通过分 析发现, 野外土壤的含水量和 $\mathrm{pH}$ 值都在不同程度 上影响了丛枝菌根真菌的侵染, 并且菌根真菌的侵 染与野生型澳大利亚粟籽豆的叶片和种子中粟籽豆 碱的含量有关。同时他们在温室内进行丛枝菌根真 菌接种试验, 研究粟籽豆碱的代谢变化规律, 也发现 粟籽豆的叶片中粟籽豆碱的含量与丛枝菌根真菌的 侵染密切相关。随后, 他们又进行了接种丛枝菌根 真菌和磷素营养供给的试验, 发现粟籽豆碱的含量 与磷素处理无关, 而与菌根真菌的侵染率呈正相关。 这表明菌根真菌的确诱导了生物碱的合成和积累, 使得植物的次生代谢对菌根真菌的侵染做出响应。 在比较了野生型和栽培型的粟籽豆叶片中粟籽豆碱 的含量之后，他们发现野生型的粟籽豆碱含量高于 栽培型。接着他们分别用根内球囊霉和珠状巨孢囊 霉( Gigaspora margarita) 接种澳大利亚粟籽豆, 发现 根内球囊霉比珠状巨孢囊霉形成的菌根植物表现出 更好的生长反应、更高的菌根真菌侵染率和粟籽五 碱含量。可见，丛枝菌根真菌的种类不仅影响植物 的生长, 也影响被接种植物中的生物碱含量。

\section{4 结 语}

丛枝菌根真菌与植物次生代谢的关系在近 20 年受到关注，一些工作已经观察到丛枝菌根真菌与 植物某些次生代谢的调控有关，丛枝菌根真菌能够 直接或间接地影响植物的次生代谢过程, 有些工作 已经从细胞及分子水平探讨其间的作用机制。然 而, 总体看来相关的工作数量有限、研究水平尚待提 高。而且, 从植物次生代谢的角度看, 关于萜类和酚 类物质的研究较多, 而有关生物碱的工作相对较少。 因此, 还需要加强丛枝菌根真菌对植物生物碱代谢 影响的研究。此外, 今后的研究还需要在以下两方 面深入展开，即丛枝菌根真菌诱导植物次生代谢的 分子机制以及丛枝菌根真菌、植物及生态因子三者 之间的相互作用。

植物次生代谢是植物生命过程的重要组成部 分, 并且与植物所生存的环境关系密切。从某种意 义上讲，丛枝菌根真菌对植物的侵染及共生也属于 
菌根植物生存环境的一部分。深入研究丛枝菌根真 菌对植物次生代谢的影响机制, 有利于人们深刻认 识丛枝菌根真菌与植物的共生关系, 也可为深入探 讨植物与环境之间的生态关系辟出新的途径。同 时 植物的次生代谢产物也是药物 (如长春花生物碱 等)和化工原料(如橡胶等)的重要来源。丛枝菌根 真菌与植物次生代谢关系的探索和阐明, 也有利于 人类更有效地利用包括传统中药药源植物在内的各 种资源植物。

\section{参 考 文 献}

Abu-Zeyad R, Khan AG, Khoo C (1999). Occurrence of arbuscular mycorrhiza in Castanospermum australe A. Cunn. \& C. Fraser and effects on growth and production of castanospermine. Mycorrhiza, 9, $111-117$.

Akiyama K, Hayashi H (2002). Arbuscular mycorrhizal funguspromoted accumulation of two new triterpenoids in cucumber roots. Bioscience Biotechnology and Biochemistry, 66, $762-$ 769 .

Akiyama K, Matsuoka H, Hayashi H (2002). Isolation and identification of a phosphate deficiency-induced C-glycosyl flavonoid that stimulates arbuscular mycorrhiza formation in melon roots. Molecular Plant-Microbe Interactions, 15, 334 - 340 .

Augé RM (2001) . Water relations, drought and vesicular-arbuscular mycorrhizal symbiosis. Mycorrhiza, 11, 3-42.

Barker SJ, Tagu D (2000). The roles of auxins and cytokinins in mycorrhizal symbioses. Journal of Plant Growth Regulation, 19, $144-154$.

Blilou I, Ocampo JA, García-Garrido JM (2000) . Induction of LTP (lipid transfer protein) and PAL (phenylalanine ammonia-lyase) gene expression in rice roots colonized by the arbuscular mycorrhizal fungus Glomus mosseae. Journal of Experimental Botany, $51,1969-1977$.

Chen DH (陈大华), Ye HC (叶和春), Li GF (李国凤), Liu Y (刘彦) (2000). Advances in molecular biology of plant isoprenoid metabolic pathway. Acta Botanica Sinica (植物学报), 42, 551 - 558. (in Chinese with English abstract)

Chen XY (陈晓亚), Ye HC (叶和春) (1998). Secondary metabolism and its regulation in plants. In: Li CS (李承森) ed. Advances in Plant Sciences Vol.1 (植物科学进展 (第一卷)). Higher Education Press, Beijing, 293 - 304. (in Chinese)

Codignola A, Verotta L, Spanu P, Maffei M, Scannerini S, Bonfante-Fasolo P (1989). Cell wall bound-phenols in roots of versicular-arbuscular mycorrhizal plants. New Phytologist, 112, 221 -228 .

Danneberg G, Latus C, Zimmer W, Hundeshagen B, Schneiderpoetsch H, Bothe H (1993). Influence of versicular-arbuscular mycorrhiza on phytohormone balances in maize (Zea mays L.). Journal of Plant Physiology, 141, 33 - 39 .

Dehne HW, Schönbeck F (1979). Investigations on the influence of endotrophic mycorrhiza on plant diseasea. II . Phenol metabolism and lignification. Phytopathology, 95, 210-216.

Devi MC, Reddy MN (2002). Phenolic acid metabolism of groundnut (Arachis hypogaea L.) plants inoculated with VAM fungus and Rhizobium. Plant Growth Regulation, 37, $151-156$.

Dodd JC, Dougall TA, Clapp JP, Jeffries P (2002). The role of arbuscular mycorrhizal fungi in plant community establishment at Samphire Hoe, Kent, UK the reclamation platform created during the building of the Channel tunnel between France and the UK. Biodiversity and Conservation, 11, 39-58.

Fester T, Maier W, Strack D (1999). Accumulation of secondary compounds in barley and wheat roots in response to inoculation with an arbuscular mycorrhizal fungus and co-inoculation with rhizosphere bacteria. Mycorrhiza, 8, 241-246.

Fester T, Schmidt D, Lohse S, Walter MH, Giuliano G, Bramley PM, Fraser PD, Hause B, Strack D (2002a). Stimulation of carotenoid metabolism in arbuscular mycorrhizal roots. Planta, $216,148-154$.

Fester T, Hause B, Schmidt D, Halfmann K, Schmidt J, Wray V, Hause G, Strack D (2002b). Occurrence and localization of apocarotenoids in arbuscular mycorrhizal plant roots. Plant Cell Physiology, 43, 256-265.

Fraser LH, Grime JP (1999). Aphid fitness on 13 grass species: a test of plant defence theory. Canadian Journal of Botany, 77, $1783-1789$.

Graham JH (2001). What do root pathogens see in mycorrhizas? New Phytologist, 149, 357 - 359 .

Grandmaison J, Olah GM, van Calsteren MR, Furlan V (1993). Characterization and localization of plant phenolics likely involved in the pathogen resistance expressed by endomycorrhizal roots. Mycorrhiza, 3, 155 - 164 .

Gupta ML, Prasad A, Ram M, Kumar S (2002). Effect of the vesicular-arbuscular mycorrhizal (VAM) fungus Glomus fasciculatum on the essential oil yield related characters and nutrient acquisition in the crops of different cultivars of menthol mint (Mentha arvensis) under field conditions. Bioresource Technology, 81, $77-79$.

Hamel C (1996) . Prospects and problems pertaining to the management of arbuscular mycorrhizae in agriculture. Agriculture, $E$ cosystems and Environment, 60, $197-210$.

Hans J, Hause B, Strack D, Walter MH (2004) . Cloning, characterization, and immunolocalization of a mycorrhiza-inducible 1deoxy-d-xylulose 5-phosphate reductoisomerase in arbuscule-containing cells of maize. Plant Physiology, 134, 614-624.

Harborne JB (1988). Introduction to Ecological Biochemistry. 3rd edn. Academic Press, London.

Harrison MJ (1999). Molecular and cellular aspects of the arbuscular mycorrhizal symbiosis. Annual Review of Plant Physiology and Plant Molecular Biology, 50, 361 - 389.

Harrison MJ, Dixon RA (1993). Isoflavonoid accumulation and expression of defense gene transcripts during the establishment of 
vesicular-arbuscular mycorrhizal associations in roots of Medicago truncatula. Molecular Plant-Microbe Interactions, 6, 643-654.

Hause B, Maier W, Miersch O, Kramell R, Strack D (2002). Induction of jasmonate biosynthesis in arbuscular mycorrhizal barley roots. Plant Physiology, 130, 1213 - 1220 .

Hohnjec N, Vieweg MF, Pühler A, Becker A, Küster H (2005). Overlaps in the transcriptional profiles of Medicago truncatula roots inoculated with two different Glomus fungi provide insights into the genetic program activated during arbuscular mycorrhiza. Plant Physiology, 137, 1283 - 1301 .

Hooker JE, Jaizme-Vega M, Atkinson D (1994). Biocontrol of plant pathogens using arbuscular mycorrhizal fungi. In: Gianinazzi S, Schüepp H eds. Impact of Arbuscular Mycorrhizas on Sustainable Agriculture and Natural Ecosystems. Birkhauser-Verlag, Basel, Switzerland, $191-200$.

Janardhanan KK, Abdul-Khaliq K (1995). Influence of vesicular arbuscular mycorrhizal fungi on growth and productivity of German chamomile in alkaline usar soil. In: Adholeya A, Singh S eds. Mycorrhizae: Biofertilizers for the Future. Tata Energy Research Institute, New Delhi, India, 410 - 412.

Jones MD, Durall DM, Tinker PB (1998) . A comparison of arbuscular and ectomycorrhizal Eucalyptus coccifera growth response, phosphorus uptake efficiency and external hyphal production. New Phytologist, 140, 125 - 134 .

Klingner A, Bothe H, Wray V, Marner FJ (1995). Identification of a yellow pigment formed in maize roots upon mycorrhizal colonization. Phytochemistry, 38, 53-55.

Krishna KR, Bgyaraj DJ (1984). Phenols in mycorrhizal roots of Arachis hypogaea. Experientia, 40, 85-86.

Larose G, Chênevert R, Moutoglis P, Gagné S, Piché Y, Vierheilig H (2002). Flavonoid levels in roots of Medicago sativa are modulated by the developmental stage of the symbiosis and the root colonizing arbuscular mycorrhizal fungus. Journal of Plant Physiology, 159, $1329-1339$.

Leng PS (冷平生), Su SC (苏淑钗), Li YH (李月华), Wang SS (王沙生), Jiang XN (蒋湘宁) (2001). Effects of fertilier and drought stress on growth as well as flavonol glycosides and terpene lactone content of Ginkgo biloba seedlings. Journal of Beijing Agriculture College (北京农学院学报), 16, 32-37. (in Chinese with English abstract)

Liu RJ (刘润进)，Li XL (李晓林) (2000). Arbuscular Mycorrhiza and Application (丛枝菌根及其应用). Science Press, Beijing, 9. (in Chinese)

Lois LM, Rodriguez-Concepcion M, Gallego F, Campos N, Boronat A (2000) . Carotenoid biosynthesis during tomato fruit development: regulatory role of 1-deoxy-D-xylulose 5-phosphate synthase. Plant Journal, 22, $503-513$.

Maier W, Peipp H, Schmidt J, Wray V, Strack D (1995). Levels of a terpenoid glycoside (blumenin) and cell wall-bound Phenolics in some cereal mycorrhizas. Plant Physiology, 109, $465-$ 470 .
Maier W, Hammer K, Dammann U, Schulz B, Strack D (1997). Accumulation of sesquiterpenoid cyclohexenone derivatives induced by an arbuscular mycorrhizal fungus in members of the Poaceae. Planta, 202, 26-42.

Maier W, Schneider B, Strack D ( 1998 ). Biosynthesis of sesquiterpenoid cyclohexenone derivatives in mycorrhizal barley roots proceeds via the glyceraldehyde 3-phosphate/pyruvate pathway. Tetrahedron Letters, 39, $521-524$.

Maier W, Schmidt J, Wray V, Walter MH, Strack D (1999). The arbuscular mycorrhizal fungus, Glomus intraradices, induces the accumulation of cyclohexenone derivatives in tobacco roots. Planta, 207, 620-623.

Massei G, Hartley SE, Bacon PJ (2000). Chemical and morphological variation of Mediterranean woody evergreen species: do plants respond to ungulate browsing? Journal of Vegetation Science, $11,1-8$.

Morandi D (1996). Occurrence of phytoalexins and phenolic compounds in endomycorrhizal interactions, and their potential role in biological control. Plant and Soil, 185, 241-251.

Morandi D, Bailey JA, Gianinazzi-Pearson V (1984) . Isoflavonoid accumulation in soybean roots infected with versicular-arbuscular mycorrhizal fungi. Physiological Plant Pathology, 24, 357 364 .

Peipp H, Maier W, Schmidt J, Wray V, Strack D (1997). Arbuscular mycorrhizal fungus-induced changes in the accumulation of secondary compounds in barley roots. Phytochemistry, 44, 581 -587 .

Ponce MA, Scervino JM, Erra-Balsells R, Ocampo JA, Godeas AM (2004). Flavonoids from shoots and roots of Trifolium repens (white clover) grown in presence or absence of the arbuscular mycorrhizal fungus Glomus intraradices. Phytochemistry, 65, $1925-1930$.

Poulin MJ, Belrhlid R, Piche Y, Chenevert R (1993). Flavonoids released by carrot (Daucus carota) seedlings stimulate hyphal development of vesicular-arbuscular mycorrhizal fungi in the presence of optimal $\mathrm{CO}_{2}$ enrichment. Journal of Chemical Ecology $19,2317-2327$.

Rai M, Acharya D, Singh A, Varma A (2001). Positive growth responses of the medicinal plants Spilanthes calva and Withania somnifera to inoculation by Piriformospora indica in a field trial. Mycorrhiza, 11, 123 - 128 .

Rojas-Andrade R, Cerda-Garcia-Rojas CM, Frias-Hernandez JT, Dendooven L, Olalde-Portugal V, Ramos-Valdivia AC (2003). Changes in the concentration of trigonelline in a semi-arid leguminous plant (Prosopis laevigata) induced by an arbuscular mycorrhizal fungus during the presymbiotic phase. Mycorrhiza, 13, 49 -52 .

Shelton AL (2000). Variable chemical defences in plants and their effects on herbivore behaviour. Evolutionary Ecology Research, $2,231-249$.

Singh DP, Srivastava JS, Bahadur A, Singh UP, Singh SK 
(2004). Arbuscular mycorrhizal fungi induced biochemical changes in pea (Pisum sativum) and their effect on powdery mildew (Erysiphe pisi). Journal of Plant Diseases and Protection, $111,266-272$.

Smith SE, Read DJ (1997). Mycorrhizal Symbiosis 2nd edn. Academic Press, San Diego, 164, 233 - 289.

Spanu P, Bonfante-Fasolo P (1988). Cell-wall-bound peroxidase activity in roots of mycorrhizal Allium porrum. New Phytologist, $109,119-124$.

Stahl PD, Schuman GE, Frost SM, Williams SE (1998). Arbuscular mycorrhizae and water stress tolerance of wyoming big sagebrush seedlings. Soil Science Society of America Journal, 62, $1309-1313$.

Strack D, Fester T, Hause B, Schliemann W, Walter MH (2003) . Arbuscular mycorrhiza: biological, chemical, and molecular aspects. Journal of Chemical Ecology, 29, 1955 - 1979.

Varma A (1998). Mycorrhizae, the friendly fungi: what we know, what should we know and how do we know? In: Varma A ed. Mycorrhiza Manual. Springer, Berlin, Heidelberg, New York, 1 -24 .

Vierheilig H, Bago B, Albrecht C, Poulin MJ, Piche Y (1998). Flavonoids and arbuscular mycorrhizal fungi. In: Manthey J, Buslig B eds. Flavonoids in the Living System. Plenum Press, New York, 9-33.

Vierheiling H, Gagnon H, Strack D, Maier W (2000) . Accumulation of cyclohexenone derivatives in barley, wheat and maize roots in response to inoculation with different arbuscular mycorrhizal fungi. Mycorrhiza, 9, $291-293$.
Vierheilig H (2004) . Regulatory mechanisms during the plant-arbuscular mycorrhizal fungus interaction. Canadian Journal of Botany, 82, $1166-1176$.

Volpin H, Elkind Y, Okon Y, Kapulnik Y (1994). A vesicular arbuscular mycorrhizal fungus (Glomus intraradices) induces a defense response in alfalfa roots. Plant Physiology, 104, 683689.

Volpin H, Phillips DA, Okon Y, Kapulnik Y (1995). Suppression of an isoflavonoid phytoalexin defense response in mycorrhizal alfalfa roots. Plant Physiology, 108, 1449 - 1454.

Walter MH, Fester T, Strack D (2000). Arbuscular mycorrhizal fungi induce the non-mevalonate methylerythritol phosphate pathway of isoprenoid biosythesis correlated with accumulation of the 'yellow pigment' and other apocarotenoids. Plant Journal, 21, $571-578$.

Walter MH, Hans J, Strack D (2002) . Two distantly related genes encoding 1-deoxy-D-xylulose 5-phosphate synthases: differential regulation in shoots and apocarotenoid-accumulating mycorrhizal roots. Plant Journal, 31, $243-254$.

Wei GT (魏改堂), Wang HG (汪洪钢) (1989). Effects of VA mycorrhizal fungi on growth, nutrient uptake and effective compounds in Chinese medicinal herb Datura stramonium L. Scientia Agricultura Sinica (中国农业科学), 22, 56-61. (in Chinese with English abstract)

Yan XF (阎秀峰) (2001). Ecology of plant secondary metabolism. Acta Phytoecologica Sinica (植物生态学报), 25, 639 - 640. (in Chinese with English abstract) 